\title{
The Degree of Public Intervention for the Definition of Aid Measures and Their Financing is a Key Criterion for Evaluating a Measure as State Aid - Invoking the Economic Crisis is Not a Reason to Declassify the Concept of State Aid
}

Katerina Nikolaidou*

LL.M Heidelberg/King's College of London, Attorney at Law, UK

\section{Summary}

On 31 July 2002 on a complaint, the Commission of the European Communities addressed to the French Republic a request of information on a non-notified aid granted to farmers' producer organizations under contingency plans to farmers' organizations of season fruit and vegetables. The grant was given from the Office national inter professionnel des fruits (hereinafter Oniflhor) and an operational fund managed by approved financial committees. These payments were to mitigate the effects of the temporary redundancy in supply of fruits, stabilizing market prices by a coordinated collective approach and to finance of structural measures that will allow the adjustment of prices in the market.

By letter of 20 July 2005, the Commission informed the French Republic of its decision to open the formal investigation procedure laid down in Article 108(2) TFEU. The outcome of the formal investigation led the Commission to adopt a decision in 2009 on the contingency plans in the fruit and vegetables as part of marketing programs (hereinafter the contested decision). In the contested decision, the Commission considered that the aid granted to producers' organizations constitute State aid is illegal and incompatible with the common market. For this reason requested that the aid must be recovered by the French Republic, with interest, from its beneficiaries.

The French Republic, producers of French fruit and vegetables and fruit and vegetables Federation of France (Fédération de l'Organisation Economique Fruits et Legumes hereinafter: Fedecom) lodge an appeal seeking annulment of the Commission's decision. The French Republic invokes as plea the infringement of the duty to state reasons. The Commission failed to justify the extension of the classification as State aid the measures financed by voluntary contributions of professionals in the concerned sector. Furthermore, it submits an error of law regarding the meaning of State aid, as European Commission described the measures as State aid, even though they are financed by private funds that paid optional and without public intervention. These measures cannot be considered that they grant advantages through State resources. Additionally, Fedecom and producers raised as plea the infringement of the doctrine of legitimate expectations. They adduced as a reason the European Commission's inactivity on a period of ten years (1992-2002), while it should have been informed about the existence of the contingency plans and this has as consequence the creation of producers' expectations confidence to the fact that the plans are lawfulness.

The Court dismissed the appeals against the decision and declared the State Aid in fruit and vegetables sector as incompatible, paid from an operational fund managed by the approved economic agricultural committees financed by sectoral contributions.

\section{The Court's Position on the Allegations}

\section{Duty to state reasons}

The French Republic declares with the first plea in law that the decision is vitiated by a lack of reasoning, as the Commission did not give detailed reasons for its view that the measures financed by the voluntary contributions of producers constitute state aid under the article 107 (1) TFEU.

The principle of justification the regulatory and administrative regulations of the European institutions based on Article 263 (2) TFEU. At this point it is important to stress that poor or inadequate reasons constitutes ground of infringement of an essential procedural requirement as a matter of public policy, which the European Union judicature has the ability to detected itself [1].

By virtue of the consisted case -law of the Court of Justice, the duty to state reasons established on Article 263 TFEU have to be adapted on the nature of the act and allow to emerge from this clearly and unequivocally the reasoning of the institution which adopted the measure [2]. The interested parties need to know precisely the reasons for the measure in order to defend their rights and to provide the competent court to exercise control over the legality of the act [3]. However it is not necessary to analyze all the relevant facts and points of law. Indeed, the question whether the statement of decision meets the requirements of Article 263 of the Treaty must be assessed with regard not only to its wording but also to its context and to all the legal rules governing the matter in question [4].

The General Court in this dispute ruled that the Commission expressly, clearly and unequivocally considered whether the measures that are financed by both state aid and voluntary contributions of producers, constitute State aid. According to the Court's view, the reasoning of the Commission's act, which for its adoption based on the case law and has been held on a broad interpretation of state aid in order to include the concept and the voluntary contributions of producers, cannot be characterized as insufficient [5]. In the present case, the

*Corresponding author: Katerina Nikolaidou, LL.M Heidelberg/King's College of London, Attorney at Law, UK, Tel: +44-20-7836-5454, E-mail: kanikolai@hotmail.com

Received May 05, 2014; Accepted November 10, 2014; Published November 17, 2014

Citation: Nikolaidou K (2014) The Degree of Public Intervention for the Definition of Aid Measures and Their Financing is a Key Criterion for Evaluating a Measure as State Aid - Invoking the Economic Crisis is Not a Reason to Declassify the Concept of State Aid. Intel Prop Rights 2: 132. doi:10.4172/2375-4516.1000132

Copyright: (c) 2014 Nikolaidou K. This is an open-access article distributed under the terms of the Creative Commons Attribution License, which permits unrestricted use, distribution, and reproduction in any medium, provided the original author and source are credited. 
Citation: Nikolaidou K (2014) The Degree of Public Intervention for the Definition of Aid Measures and Their Financing is a Key Criterion for Evaluating a Measure as State Aid - Invoking the Economic Crisis is Not a Reason to Declassify the Concept of State Aid. Intel Prop Rights 2: 132. doi:10.4172/2375-4516.1000132

Page 2 of 3

General Court stated that it was the first time regarding enter these contributions to the concept of State aid, providing the Commission the discretion of interpretation the meaning. The Commission found that despite the voluntary nature of contributions provided financial incentives to producers. Furthermore, the degree of precision of the statement of the reasons for the decision is required to be proportional to the practical realities and the time and technical facilities available for making decisions [6].

\section{Meaning of state aid - the benefits granted by private bodies which are established by the state constitute state aid. criterion for the assessment of state aid is the degree of state intervention in the aid measures.}

The peculiarity of this case focuses on the fact that these measures were partly funded by voluntary contributions from the sector. The French Republic refused the existence of state aid on the ground that the condition relating to the existence of State resources is lacking.

Article 107 TFEU separates the aid between 'aid granted by the State' and those granted 'through State resources'. According to consisted case-law is not considered that all advantages granted by State, whether financed through state resources or not, constitute aid. This provision is intended to include both advantages which are granted directly by the State, and the advantages granted by public or private bodies designated or established by the State [7]

In this case the General Court hereinafter GC stressed that the voluntary nature of contributions is not enough to remove the character of the aid scheme. According to GC appropriate criterion for assessing the existence of public resources is the degree of intervention of public authorities in determining these measures and financing arrangements. According to the Court, the voluntary nature of the contributions is not sufficient enough for the non-existence of state aid. The provision of Article 107 (1) TFEU includes all financial instruments that may be used by the public sector to support undertakings, irrespective of whether the fact that these instruments are or not permanent assets in this sector and therefore constitute State aid [8]. In this case the ONIFLHOR featured under French Rural Code as a vehicle for intervention in the food sector and public agency industrial and commercial under the supervision of the government, played a decisive role in financing. Basically, it approved the aid, which was then covered by a rate of 50 to 70 percent of public aid. The administrative authorities controlled constantly the amounts and agricultural economic committees. The concept of state resources on Article 107 (1) TFEU includes all the financial instruments issued by public authorities, without the meaning that they are permanent assets of the said public authorities. The fact that they constantly remain under public control and therefore available to the competent national authorities, is sufficient enough to be qualified as state resources. Similarly, the nature of resources as private does not prevent their classification as State resources within the meaning of Article 107 paragraph 1 TFEU [9].

\section{The principle of legitimate expectations}

Finally, the producers of French fruit and vegetables and the fruit and vegetables Federation of France (Fédération de l'Organisation Economique Fruits et Legumes Fedecom) argued that the contested decision infringes the principle of legitimate expectations, given that, despite the fact that the Commission was informed about the existence of these programs through the control mechanisms, and the report on the existence of marketing programs in several articles in the French press, it took no action against them. This had as consequence the conviction of the producers' expectations concerning the compatibility of these programs with the common market. Additionally, they relied on the Regulation ( EC ) No 1182/2007 of 26 September 2007 establishing common rules especially for fruit and vegetables ( OJ L 273, p.1 ), which provides the need to implement measures for farmers during the financial crisis. According to the settled case-law, the right to invoke the principle of protection of legitimate expectations extends to any person who has reasonable expectations. At this point it is necessary to emphasized that the principle of legitimate expectations is one of the fundamental principles of the European Union [10].

The principle of legitimate expectations provided the following conditions:

Firstly, specific assurances arise unconditionally from authorized and reliable sources [11]. Secondly, those assurances must be such as to create a legitimate expectation to the person to whom they are addressed [12]. Finally, the assurances given must comply with the applicable rules [13].

The General Court considers the notification requirement as a fundamental element of the control system in the field of state aid. Under this system, Member States are required to notify the Commission any measure to grant or alter aid within the meaning of Article 107(1) TFEU. Additionally, they should not implement such a measure in accordance with Article 108 paragraph 3 TFEU if the Commission has not taken a final decision on the measure. A diligent businessman as the consequence of the mandatory nature of State aid control should normally be able to ensure that the procedure was followed [14]. In particular, where the aid is paid without prior notification to the Commission, so that it is unlawful under Article 108 paragraph 3, TFEU, the beneficiary of the aid could not, at that time, entertain a legitimate expectation that the aid is lawful unless it has been granted in compliance with the procedure laid down in that article. Invoking this principle, the claim is justified only if were proved by exceptional circumstances. The applicant in support of its plea in law relies on the Regulation (EC) No 1182/2007 of 26 September 2007 which established common rules specific for fruits and vegetables and which foresees the need to implement measures for farmers during the economic crisis. This Regulation, is not relating to that period, it does not allow any action with a similar nature to this aid and it does not constitute an exceptional circumstance capable of justifying a legitimate expectation of the applicant regarding to the nature of the aid. Finally, the Court accepts that the economic crisis affects the fruit and vegetables market. This fact can have an impact on the legal nature of aid and on the declassification as such.

\section{Conclusion}

Those decisions of the General Court are important for two main reasons. First of all they consider the key criterion for assessing the existence of State aid, regardless of their origin, which is the degree of intervention of public authorities on determining these measures and their financing. The argument that the contributions of actors are optional and not mandatory in nature is not enough to undermine this principle. The degree of intervention by public authorities on contributions can be significant, even if the contributions are not mandatory

Secondly, according to the General Court, invoking the principle of legitimate expectations may have effect only if the applicant proves the existence of exceptional circumstances to justify the granting of state 
Citation: Nikolaidou K (2014) The Degree of Public Intervention for the Definition of Aid Measures and Their Financing is a Key Criterion for Evaluating a Measure as State Aid - Invoking the Economic Crisis is Not a Reason to Declassify the Concept of State Aid. Intel Prop Rights 2: 132. doi:10.4172/2375-4516.1000132

Page 3 of 3

aid. The economic crisis actually affects the horticultural industry but cannot call into question the legal nature of state aid and to declassify it.

\section{References}

1. Krajewski/Rösslein in : Das Recht der Europäischen Union (2011) Kommmentar III, Art. 296, Verlag C.H. Beck.

2. Case C-108/81 (1982) Amylum v Council, ECR- 3107.

3. Case C- 57/00 P, C- 61/00 P (2003) Freistaat Sachsen etc. v Commission ECL I-9975.

4. Case C- 344/04 (2006) IATA etc./ Department for Transport. ECR, I-403

5. Judgment of the Court (1987) French Republic $v$ Commission of the European Communities. State aid - Textile and clothing sector: Case 259/85.

6. Judgment of the Court ((1990) Société française des Biscuits Delacre e.a. v Commission of the European Communities. - Agriculture - Aid for butter for use in the manufacture of pastry products - Tendering procedure - Commission decision reducing the level of aid - Action for annulment. - Case C: 350/88.
7. Judgment of the Court (PreussenElektra $A G \vee$ Schhleswag) $A G$, in the presence of Windpark Reußenköge III GmbH and Land Schleswig-Holstein - Reference for a preliminary ruling: Landgericht Kiel - Germany. - Electricity Renewable sources of energy - National legislation requiring electricity supply undertakings to purchase electricity at minimum prices and apportioning the resulting costs between those undertakings and upstream network operators - State aid - Compatibility with the free movement of goods. - Case C: 379/98.

8. Case, T-358/94 (1996) Air France v Commission. ECR II-2109.

9. Case T-358/94 (1996) Air France v Commission. ECR II-2109.

10. Case C-265/85 (1987) Van den Berghen Jurgens BV and Van Dijk Food Products (Lopik) BV, ECR.

11. Case T-66/96, T-221/97 (1998) Mellett v Court of Justice. ECR II-1305: 106107.

12. Case T-56/96 (1998) Maccaferri v Commission. ECR 133: 54.

13. Case T-347/03 (2005) Branco v Commission. ECR II, 2555: 102.

14. Case C-5/89 (1990) Commission v Germany. ECR 3437: 14. 